Subscriber access provided by UNIV NEW ORLEANS

\title{
Article
}

\section{Micro-mesoporous activated carbons as catalysts for the efficient oxidation of aqueous sulfide}

Mateus Carvalho Monteiro de Castro, Igor Tadeu Cunha, Fernanda Gomes de Mendonça, Rodinei Augusti, João Paulo de Mesquita, Maria Helena Araujo, Manuel Martínez-

Escandell, Miguel Molina Sabio, Rochel Montero Lago, and Francisco Rodriguez-Reinoso

Langmuir, Just Accepted Manuscript • DOI: 10.1021/acs.langmuir.7b01499 • Publication Date (Web): 28 Sep 2017

Downloaded from http://pubs.acs.org on October 9, 2017

\section{Just Accepted}

"Just Accepted" manuscripts have been peer-reviewed and accepted for publication. They are posted online prior to technical editing, formatting for publication and author proofing. The American Chemical Society provides "Just Accepted" as a free service to the research community to expedite the dissemination of scientific material as soon as possible after acceptance. "Just Accepted" manuscripts appear in full in PDF format accompanied by an HTML abstract. "Just Accepted" manuscripts have been fully peer reviewed, but should not be considered the official version of record. They are accessible to all readers and citable by the Digital Object Identifier (DOI®). "Just Accepted" is an optional service offered to authors. Therefore, the "Just Accepted" Web site may not include all articles that will be published in the journal. After a manuscript is technically edited and formatted, it will be removed from the "Just Accepted" Web site and published as an ASAP article. Note that technical editing may introduce minor changes to the manuscript text and/or graphics which could affect content, and all legal disclaimers and ethical guidelines that apply to the journal pertain. ACS cannot be held responsible for errors or consequences arising from the use of information contained in these "Just Accepted" manuscripts. 


\title{
Micro-mesoporous activated carbons as catalysts for the efficient
} oxidation of aqueous sulfide

Mateus Carvalho Monteiro de Castro, $^{a}$ Igor Tadeu Cunha ${ }^{a}$, Fernanda Gomes de Mendonça, ${ }^{a}$ Rodinei Augusti, ${ }^{a}$ Joao Paulo de Mesquita, ${ }^{b}$ Maria Helena Araujo, ${ }^{a}$ Manuel Martínez Escandell, ${ }^{c^{*}}$ Miguel Molina Sabio, ${ }^{c}$ Rochel Montero Lago, $^{a}$ Francisco Rodríguez Reinoso. ${ }^{c}$

a Departamento de Química, Universidade Federal de Minas Gerais, Belo Horizonte, Brazil

${ }^{\mathrm{b}}$ Departamento de Química, Universidade Federal de Vale do Jequitinhonha e Mucuri, Diamantina, Brazil.

c Laboratorio de Materiales Avanzados, Departamento de Química Inorgánica, Universidad de Alicante, Spain

*Corresponding Author: E-mail: manolo.m@ua.es.

\begin{abstract}
$\mathrm{KOH}$ activation of a mesophase pitch produces very efficient carbons for the removal of sulfide in aqueous solution, increasing sulfur oxidation rate with the degree of activation of the carbon. These carbons are characterized by their graphitic structures, with domains of sizes around $20 \mathrm{~nm}$, and a moderate amount of surface oxygen groups $\left(0.2-0.5 \mathrm{mmol}^{-1}\right)$, predominating the basic groups. As the activation leads first to a strong development of the micropores and later to a development of the mesopores, the surface area values are always high, reaching values as high as $3250 \mathrm{~m}^{2} \cdot \mathrm{g}^{-1}$ in the most activated
\end{abstract}


carbon, with a volume of mesopores as high as $44 \%$ of the total pore volume. In the presence of this carbon the sulfide oxidation rate is 100 times higher than that found for a commercial activated carbon, the results indicating that the porosity of the carbon, especially mesoporosity, plays a role more important than the structure or the chemical nature of the carbon in the kinetics of sulfide oxidation to different polysulfides. 


\section{Introduction}

Sulfide is present in many industrial wastewater treatment plants ${ }^{1-3}$, and in a wide $\mathrm{pH}$ range leads to the formation of unpleasant, toxic and corrosive $\mathrm{H}_{2} \mathrm{~S}$ gas ${ }^{4}$. The removal of hydrogen sulfide from gas phase by means of adsorption ${ }^{5,6}$ and catalytic oxidation with air ${ }^{7,8}$ has been relatively well studied, whereas the elimination of sulfide from aqueous media has only been described in few reports. Simple precipitation ${ }^{9}$ with large amount of chemicals has many drawbacks so that greener and more cost-effective processes are necessary.

Biological processes have shown promising results ${ }^{10}$. It has been suggested that a sulfide-quinone reductase is essential for the growth of some sulfur-oxidizing bacteria with the ability to convert sulfide into sulfur and/or sulfate, this enzymatic process taking place via quinone redox group ${ }^{11}$. Studies on the reaction mechanism of the addition of hydrogen sulfide to juglone (5hydroxy-1,4-naphthalenedione) also highlight the fundamental role of quinone groups for the oxidation of sulfide ${ }^{12}$.

Although it is well known that activated carbon catalyzes sulfide oxidation in aqueous solution ${ }^{13}$, recent studied carried out using carbon/ $/ \mathrm{e}_{3} \mathrm{O}_{4}$ composites ${ }^{10}$, activated carbon ${ }^{14}$, graphite and graphene ${ }^{15}$ chemically modified to introduce surface quinone groups, not only have shown that these groups directly participate in the oxidation reaction but also that the graphitic structures of the carbon may help in the transference of the electron.

In this work, a remarkable set of nanostructured carbons with high surface area values and different proportions of micro- and mesopore volumes have been tested to study their influence in the kinetics of sulfide oxidation in aqueous solution. The role of oxygen surface groups, as active sites of the oxidation, the 
presence of graphitic domains in the structure of the carbon, as a facile electron transportation system, and the porosity, related to the accessibility to active sites, have been evaluated.

\section{Experimental}

\section{Preparation of the activated carbons}

A mesophase pitch, obtained by the pyrolysis of an ethylene $\operatorname{tar}^{16}$ has been mixed with potassium hydroxide $(\mathrm{KOH}$ : $\mathrm{C}$ weight ratios $1: 1,3: 1$ and $6: 1)$ in a ball-mill to a particle size of $20 \mu \mathrm{m}$. The mixture has been heated to $800{ }^{\circ} \mathrm{C}$ for $2 \mathrm{~h}$ in a $100 \mathrm{~mL} / \mathrm{min} \mathrm{N}_{2}$ flow to obtain the activated carbons PA 1:1, PA 3:1 and PA 6:1 after washing with $10 \% \mathrm{HCl}$ and with distilled water until neutral $\mathrm{pH}$. Additionally, the carbon PA 6:1 has been treated with $\mathrm{HNO}_{3}$ acid at $80^{\circ} \mathrm{C}$ for 30 min to increase the total amount of surface groups without changing the porosity significantly ${ }^{17}$. Other metal-containing activated carbons (P2NiA 3:1 and P2CuA 3:1) have been prepared under the same conditions as those of carbon PA 3:1; in the preparation of these carbons, prior to the pyrolysis, acetyl acetonate of $\mathrm{Cu}$ or $\mathrm{Ni}$ has been solubilized in the ethylene tar. These activated carbons have been labeled with the letter $\mathrm{P}$ followed by a number, indicating the starting metal concentration in the petroleum residue, and the symbol of the metal, e.g. P2Ni; followed by the letter $\mathrm{A}$ indicate that it has been activated at $800^{\circ} \mathrm{C}$, and by the numbers indicating the $\mathrm{KOH}$ : carbon ratio.

In this way, the volume of mesopores can be increased without modifying significantly the volume of micropores. More details of the preparation can be found in references ${ }^{16}$. 
An activated carbon (AC) from coconut shell (Sufal) treated with $\mathrm{HCl}$ to remove mineral matter has been used for comparison. Particle size of AC, around $10-15 \mu \mathrm{m}$, is similar to that $\mathrm{KOH}$ activated carbons.

\section{Properties of the activated carbons}

The carbon structure has been studied by Raman spectroscopy using a Bruker 100 FT-FRS-Raman, 785 nm, 2 mW laser, and by transmission electron microscopy, employing a HITACHI S-3000 N transmission electron microscope (TEM) fitted with a XFlash 3001 dispersive X-ray analyzer.

$\mathrm{N}_{2}$ adsorption isotherms at $-196^{\circ} \mathrm{C}$ have been obtained using a N2Gsorb6 apparatus. The Dubinin Radushkevich method has been used to obtain the micropore volume $\left(\mathrm{V}_{\text {Micro }}\right)$. The total pore volume $\left(\mathrm{V}_{\text {Total }}\right)$ is estimated as the amount of $\mathrm{N}_{2}$ adsorbed by the activated carbon at a 0.95 relative pressure ${ }^{18}$ and the volume of mesopores $\left(\mathrm{V}_{\text {Meso }}\right)$ is calcuted by difference between $\mathrm{V}_{\text {Total }}$ and $\mathrm{V}_{\text {Micro. }}$

The potentiometric titration was performed in a sealed cell with $\mathrm{N}_{2}$ purge and an automatic titrator Metrohm $670.75 \mathrm{mg}$ of activated carbon have been dispersed in $30 \mathrm{~mL} \mathrm{HCl} 0.005 \mathrm{~mol} / \mathrm{L}$ and $\mathrm{NaCl} 0.045 \mathrm{~mol} / \mathrm{L}$, and titrated with $\mathrm{NaOH} 0.050 \mathrm{~mol} / \mathrm{L}$. The data on $\mathrm{pH}$ and volume of titrant has been used to determine the amount of oxygen surface groups ${ }^{18,19}$.

\section{Sulfide oxidation}

Kinetic studies of sulfide oxidation have been carried out on stirred suspensions of $5.0 \mathrm{mg}$ of carbon with $12.0 \mathrm{~mL}$ of aqueous solution of $\mathrm{Na}_{2} \mathrm{~S} .9 \mathrm{H}_{2} \mathrm{O}\left(8.0 \mathrm{~g} . \mathrm{L}^{-1}\right)$ at $25^{\circ} \mathrm{C}$ for 1 hour. The reaction was monitored by 
measuring of the absorbance of the aqueous solutions every 5 minutes using a UV-Vis spectrophotometer (Shimadzu model UV 25550). After $30 \mathrm{~min}$ of reaction, some solutions have been analyzed by paper spray mass spectroscopy using ThermoElectron LCQFleet operating in the negative ion mode.

Three sequential oxidation experiments in the same conditions have been carried out with the carbon PA 6:1. After around 30 min of reaction the carbon has been centrifuged and a new sulfide solution was added. After the third cycle, the concentration of sulfur in the carbon has been determined by Xray fluorescence (X-Ray Rigaku-Geigerflex).

\section{Results and discussion}

\section{Structure, porous texture and surface chemistry of activated carbons.}

Raman spectra have shown that the activation led to an increase of the $D$ peak intensity in respect to peak $G$, indicating that during the activation more defective carbon structures have been produced. The detailed analysis of the Raman spectra (see supplementary material) allows estimating the size values of the graphitic domains, collected in Table 1, which seems to be around 20-30 $\mathrm{nm}$ in the activated carbons, similar to those of the pristine mesophase pitch.

Table 1. $I_{D} / I_{G}$ intensity ratios and graphitic domains estimated sizes for the different activated carbons and mesophase pitch.

Material $\quad I_{D} / I_{G} \quad$ Graphitic domain dimension/ $\mathrm{nm}$

$\begin{array}{lll}\text { PA 1:1 } & 1.35\end{array}$

6 
$\begin{array}{lll}\text { PA 3:1 } & 1.28 & 26\end{array}$

$\begin{array}{lll}\text { PA 6:1 } & 1.57 & 21\end{array}$

$\begin{array}{lll}\text { Mesophase pitch } & 0.7 & 20\end{array}$

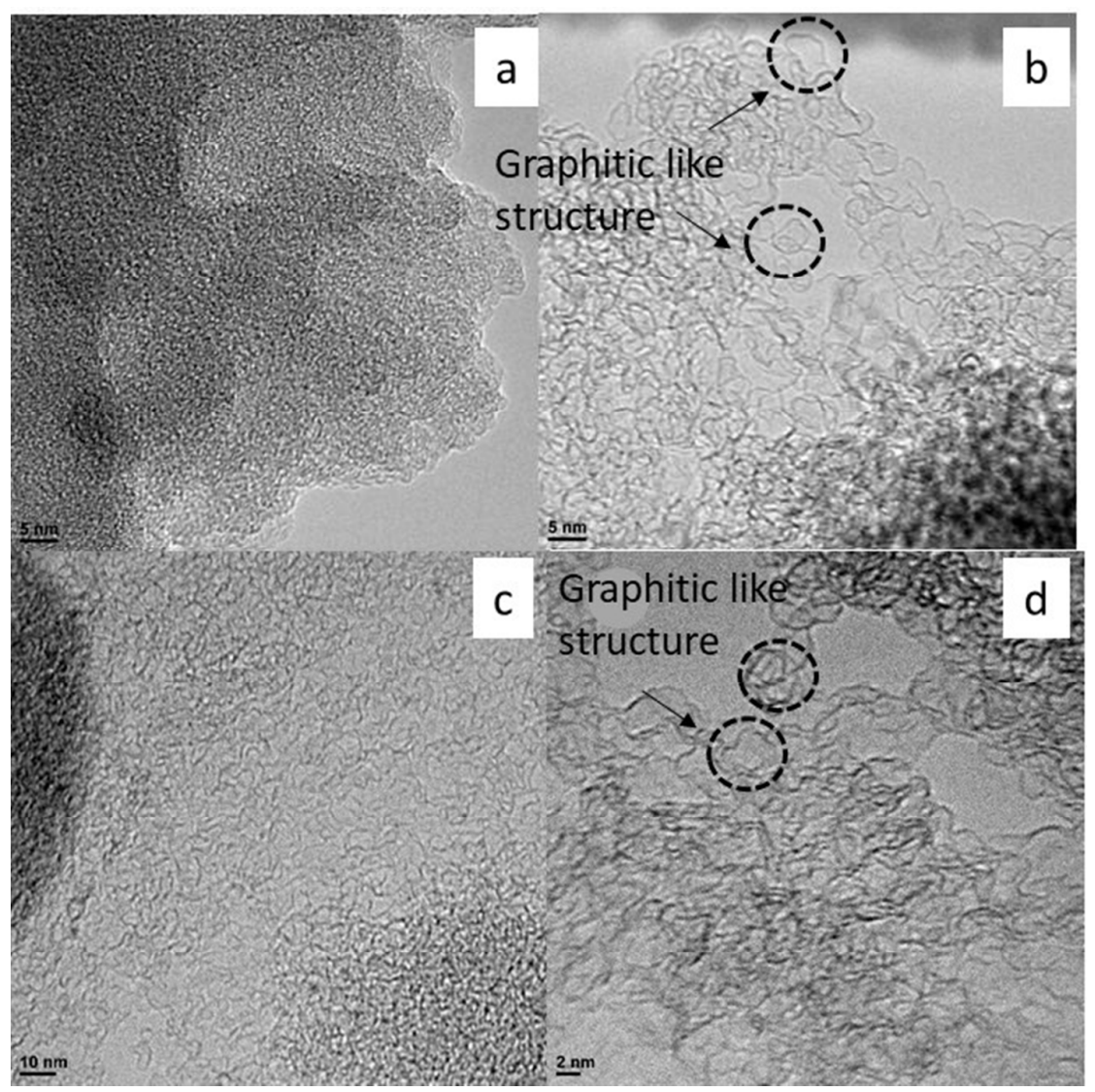

Figure 1. TEM images of (a) pitch (b) PA 1:1, (c) PA 3:1 and (d) PA 6:1.

TEM images in Figure 1 show a dense and compact structure for the mesophase pitch, while activated carbons exhibit graphitic-like structures, with dimensions ranging from $5-20 \mathrm{~nm}$, similar to those observed in previous works 20-22. It has been suggested that these graphitic structures are necessary for the oxidation of sulfide to occur as they may help in the removal and transfer of the electrons ${ }^{23}$. 
Table 2. Surface area and porosity data of the activated carbons.

\begin{tabular}{ccccc}
\hline Sample & BET $\left(\mathrm{m}^{2} / \mathrm{g}\right)$ & $\begin{array}{c}\mathrm{V}_{\text {Micro }} \\
\left(\mathrm{cm}^{3} / \mathrm{g}\right)\end{array}$ & $\begin{array}{c}\mathrm{V}_{\text {Meso }} \\
\left(\mathrm{cm}^{3} / \mathrm{g}\right)\end{array}$ & $\mathrm{V}_{\mathrm{T}}\left(\mathrm{cm}^{3} / \mathrm{g}\right)$ \\
\hline PA 1:1 & 1470 & $0.61(97 \%)$ & $0.02(3 \%)$ & 0.63 \\
PA 3:1 & 2770 & $0.95(75 \%)$ & $0.32(25 \%)$ & 1.27 \\
PA 6:1 & 3250 & $1.11(56 \%)$ & $0.88(44 \%)$ & 1.99 \\
P2NiA 3:1 & 2790 & $0.96(66 \%)$ & $0.51(34 \%)$ & 1.46 \\
P2CuA 3:1 & 2650 & $0.90(71 \%)$ & $0.36(29 \%)$ & 1.26 \\
AC & 865 & $0.37(86 \%)$ & $0.06(14 \%)$ & 0.43 \\
\hline
\end{tabular}

The porous texture of the carbons may also play an important role in the removal of sulphur. Table 2 shows that the surface area of $A C$ is much smaller than that of PA 1:1, PA 3:1 and PA 6:1 activated carbons, the values increasing with increasing $\mathrm{KOH}$ : ratio. It is also inferred that the PA $1: 1$ carbon is essentially microporous, with predominantly narrow micropores, whereas in carbon PA 6:1 the proportion of mesopores is remarkable. A more detailed study of pore development and the changes in pore size distribution during $\mathrm{KOH}$ activation of mesophase pitch can be found in previous works ${ }^{24-26}$.

Table 3 shows the amount and distribution of oxygen surface groups according to their acid or basic properties. Sites with $\mathrm{pKa}<6$ suggest the formation of carboxylic groups ${ }^{26}$, whereas lactone and lactol groups show pKa values between 7 and $9^{27}$. Basic groups as phenols and quinones have pKa greater than $9^{28}$. It can be noted that the amount of oxygen surface groups of 
PA 1:1 carbon (somewhat higher than that of the commercial $A C$ ) increases with activation, predominating in all the carbons groups with $\mathrm{pKa}>9$. The basic character of all PA carbons is expected since the activation has been carried out with a basic chemical, $\mathrm{KOH}$, and elevated temperature, $800^{\circ} \mathrm{C}$. Finally, it has to be pointed out that the $\mathrm{HNO}_{3}$ treatment of PA 6:1 carbon dramatically increases the total amount of surface groups, including the basic groups.

Tabla 3. Amount of acid, neutral and basic carbon surface groups

\begin{tabular}{ccccc}
\hline & \multicolumn{5}{c}{ Amount of groups $\left(\mathrm{mmol} . \mathrm{g}^{-1}\right)$} \\
\cline { 2 - 5 } & pKas $<6$ & $6<$ pKas $<9$ & pKas $>9$ & Total \\
\hline PA 1:1 & 0.08 & 0.06 & 0.16 & 0.30 \\
PA 3:1 & 0.12 & 0.10 & 0.33 & 0.55 \\
PA 6:1 & 0.15 & 0.09 & 0.34 & 0.58 \\
PA 6:1 HNO3 & 0.53 & 0.83 & 0.60 & 1.96 \\
AC & 0.04 & 0.03 & 0.08 & 0.15 \\
& & & & \\
\hline
\end{tabular}

\section{Oxidation of sulfides in the presence of activated carbon}

As soon as the activated carbon is added, the transparent sulfide solution becomes yellow, which shows the action of the activated carbon as a catalyst for the sulfide oxidation. The UV/Vis absorption spectra (Figure 2) show a band at $290 \mathrm{~nm}$ and another one, very wide and low intensity, with a maximum at 370nm. Similar experiments with other carbon materials led to UV/vis spectra 
exhibiting an intense band at $230 \mathrm{~nm}$, due to the absorption of $\mathrm{S}^{2-}$ and $\mathrm{HS}^{-}$ species, and others with lower intensity at 264, 300 and $370 \mathrm{~nm}$, related to the oxidation products of sulfide, $\mathrm{S}_{2}{ }^{2-}, \mathrm{S}_{3}{ }^{2-}$ and $\mathrm{S}_{4}{ }^{2-}$, respectively ${ }^{10,19,23,29}$. In the UV/Vis spectra of Figure 2 it can be observed that in the wavelength range of 290-370nm the absorbance increases with the carbon-solution contact time, indicating that there is an increase in the concentration of $\mathrm{S}_{2}{ }^{2-}(290 \mathrm{~nm})$, as well as other polysulfides, which absorb at increasing wavelengths with increasing the length of the chain ${ }^{10,19,23}$.

Figure $2 \mathrm{~b}$ shows an ESI-MS spectrum of the solution after 30 minutes reaction. The main MS signal 33 is related to $\mathrm{HS}^{-}$present in the solution. Interestingly, peaks related to the presence of polysulfide of 2 to 4 sulfur atoms, with $\mathrm{m} / \mathrm{z}$ ratios of $65\left(\mathrm{HS}_{2}{ }^{-}\right), 97\left(\mathrm{HS}_{3}{ }^{-}\right)$and $129\left(\mathrm{HS}_{4}{ }^{-}\right)$, can be clearly observed, the first one being predominant. The $\mathrm{m} / \mathrm{z}$ signals 97 and 129 could also be related to more oxidized products, i.e. $\mathrm{HSO}_{4}{ }^{-}$and $\mathrm{HS}_{2} \mathrm{O}_{4}{ }^{-}$, respectively, which have formed to a lower extent. 


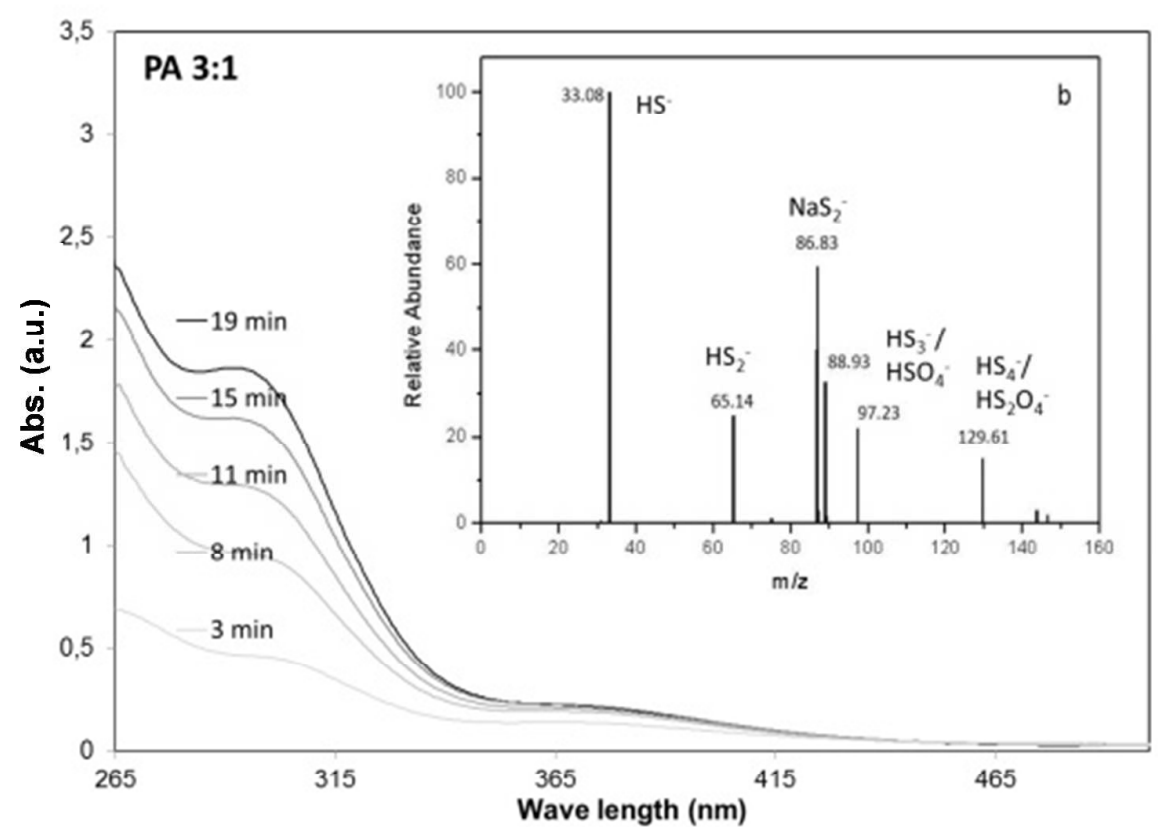

Figure 2. UV/Vis spectral evolution during sulfide oxidation using PA 3:1 and EMI-MS spectrum after 30 minutes.

The band at $290 \mathrm{~nm}$, related to the formation of the disulfide $\mathrm{S}_{2}{ }^{2-}$, has been selected for the kinetic studies of sulfide oxidation, shown in Figure 3. In all carbons, an initial linear behavior is observed, which suggests a pseudo zero order kinetics. It is remarkable that the reaction constant rates values, $\mathrm{k}$, obtained from the slope of the straight region up to $20 \mathrm{~min}$, increase from carbon PA 1:1 to PA 3:1 and PA 6:1 and these values are much higher than those of the reference activated carbon, AC. In fact, the constant rate shown by PA 6:1 multiplies per 100 that of $\mathrm{AC}$, which previously proved to be a more active catalyst than graphene and graphite ${ }^{23}$. 


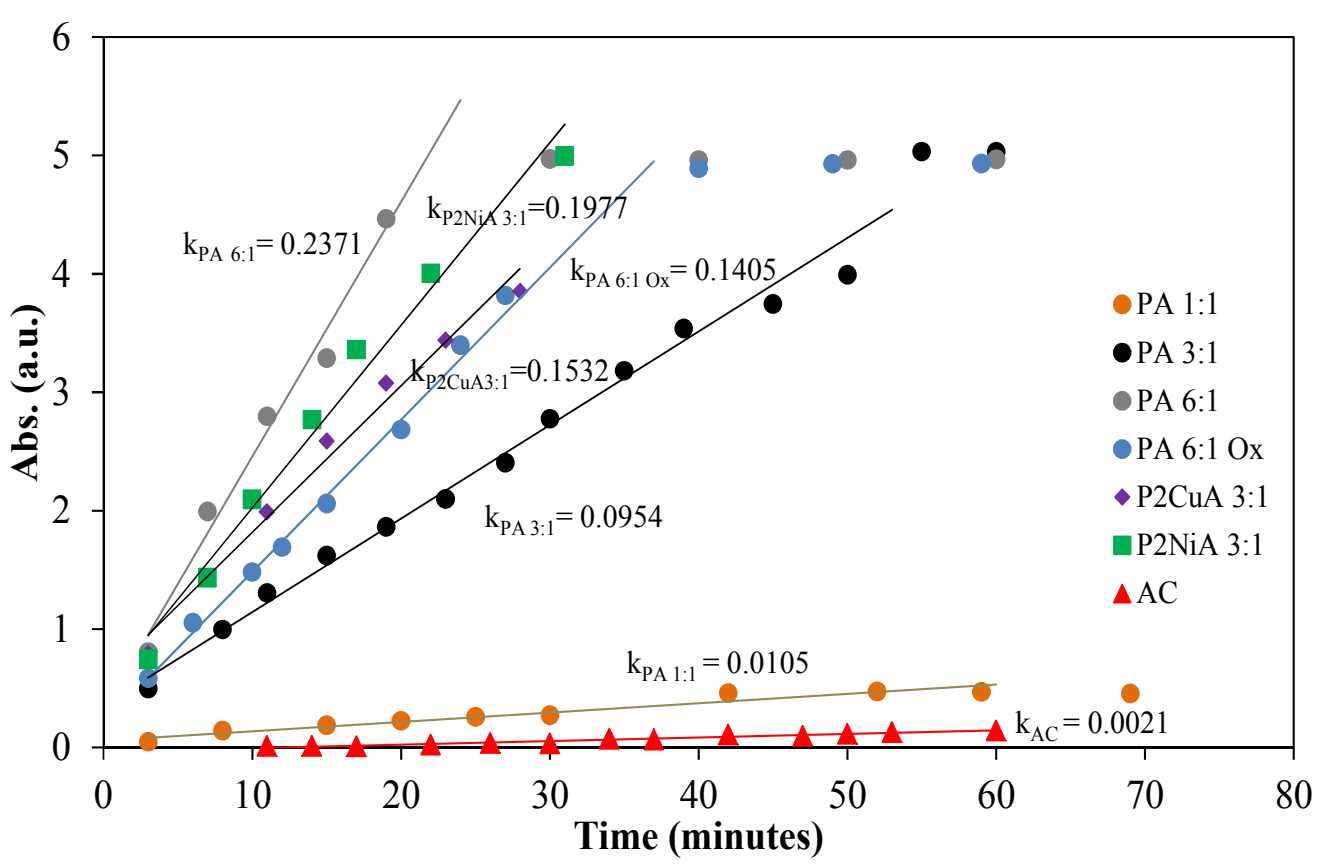

Figure 3. Sulfide oxidation monitored by the band at $290 \mathrm{~nm}$.

The high efficiency of the activated carbon PA 3:1 and especially PA 6:1 PA can be attributed, in principle, to the concentration of "active" sites. In these carbons the "active" sites should be the oxygen surface groups, since a sulfide anion will have less interaction with the carbon atoms in the graphite sheet than with the oxygen bound to the surface of the carbon. Even a larger preference for the basic than for the acids groups can be expected ${ }^{10,19,23}$, taking into account the anionic character of the sulfide. However, the correlation of the values of $\mathrm{k}$, Figure 3, with the amount of total oxygen groups, Table 3, or even with the amount of basic groups ( $\mathrm{pK}>9$ ) is not good. For instance, the amount of oxygen surface groups of the PA 3:1 and PA 6:1 carbons is similar and, although both show a similar final activity (Figure 3 ), the values of $k$ are quite different. Similarly, the strong increase in the number of oxygen surface groups due to a mild oxidation of carbon PA6:1 with $\mathrm{HNO}_{3}$ acid does not result in an 
increase in the value of $k$. Therefore, it seems that the quantity and type of oxygen surface groups are not totally responsible for the observed differences between the different carbons.

It also seems that the differences between the values of $k$ for PA activated carbons in Figure 3 are not originated by the structural changes in the carbon structure with activation, since the mean size of the graphitic domains slightly decreases with activation (Table 1 and Figure 2). However, this behavior cannot be observed with porosity, which changes dramatically with the $\mathrm{KOH}$ : C activation ratio.

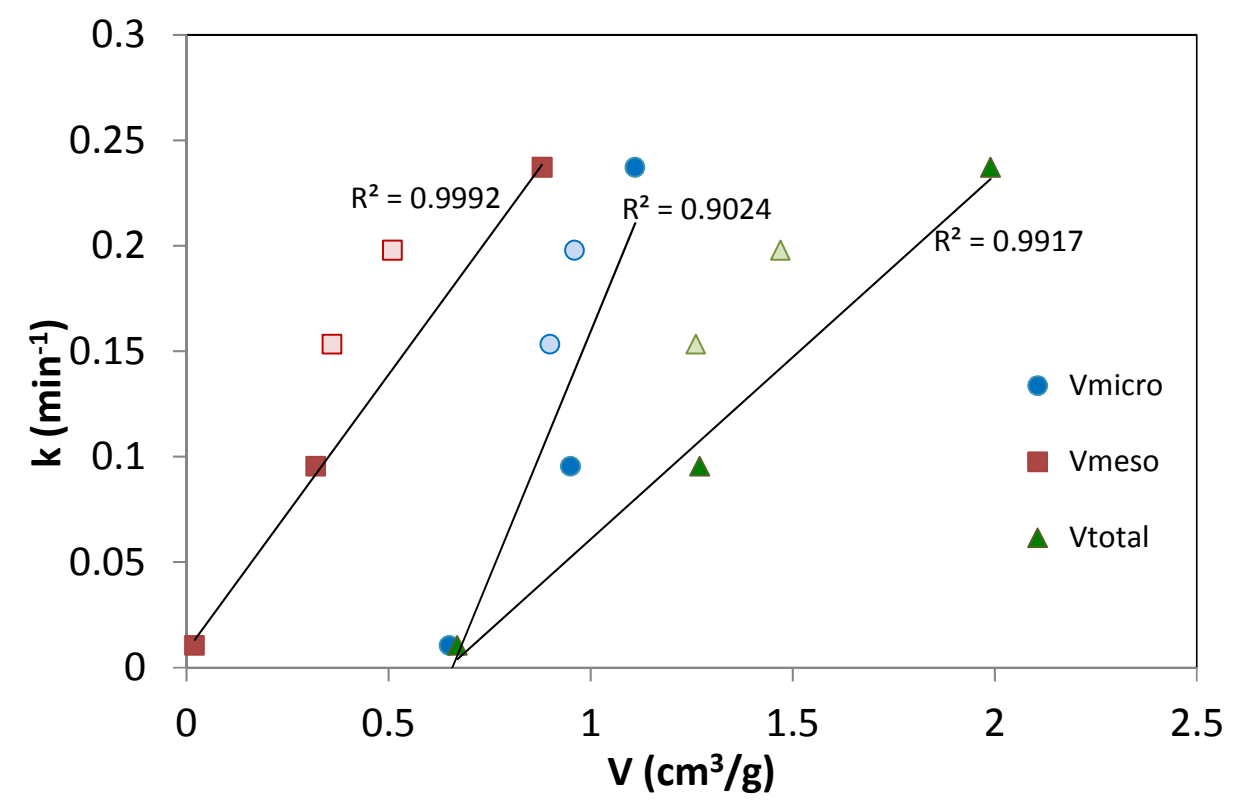

Figure 4. Relation between rate constants, $k$, and the total pore, micro and and mesopore volume

The effect of the porosity of the carbon in the rate of sulfide oxidation can be observed in Figure 4. The good correlation found between the values of $k$ and the volume of pores and mesopores for carbons PA 1:1, PA 3:1 and PA 6:1 
(darker symbols) suggests that sulfide oxidation maybe governed by the access of reactants towards the oxygen surface groups and by the exit of the products until reaching the bulk solution. It is expected that the anion $\mathrm{S}^{2-}$ (diameter $0.36 \mathrm{~nm}$ ) has some limitations to access the active sites located in the narrow micropores and that the reaction products $\left(\mathrm{S}_{2}{ }^{2-}, \mathrm{S}_{3}{ }^{2-}\right.$ and $\mathrm{S}_{4}{ }^{2}-, 0.4,0.6$ and 0.8 $\mathrm{nm}$ diameters ${ }^{30}$, respectively), once formed inside of the micropores, can get out without much difficulty ${ }^{19,23,31}$. Therefore, although the amount of oxygen groups of the carbons is large enough to achieve a good level of transformation, both efficiency and kinetics will depend on the porosity: in the PA 1:1 activated carbon the efficiency is not very high because the sulfur anions have restricted access to the narrowest micropores. However, in the carbons PA 3: 1 and PA $6: 1$ the same transformation level is reached but it occurs at different rates. In other words, when the activation is able to widen the micropores and generate mesopores, the oxidation rate is nicely improved.

One way to corroborate this idea could be use activated carbons with the same chemical nature and microporosity as the PA carbons, but with a larger volume of mesopores. Activation of mesophase pitches containing highly dispersed metal nanoparticles $(\mathrm{Cu}$ or $\mathrm{Ni})$ is a good approximation since the metals cause a local increase of the $\mathrm{KOH}-\mathrm{C}$ reaction during activation with the subsequent development of mesopores ${ }^{16}$. Table 2 shows that both P2CuA 3:1 $(9.2 \% \mathrm{Cu})$ and P2NiA $3: 1(2.6 \% \mathrm{Ni})$ have BET surface area and micropore volume values very similar to PA 3: 1, but the volume of mesopores is higher.

Figure 3 includes the kinetics data for sulfide oxidation with P2CuA and $\mathrm{P} 2 \mathrm{NiA}$ activated carbons. It is to be noted that the behavior of both carbons is similar to that observed for the carbon PA 3:1. But the most important fact is the 14 
parallelism found between the values of $k$ with the volume of mesopores. Even more, both carbons are reasonably adjusted to the trend marked in Figure 4 for PA 1:1, PA 3:1 and PA 6:1 carbons. Interestingly, all the carbons (except the reference $A C$ and $P A 1: 1$, those with predominating narrow micropororosity) reach a maximum absorbance value of 5 a.u., (Figure 3 ). In order to have a better knowledge of the reasons for this behavior, three sequential oxidation experiments with new sulfide solution have been carried out with the carbon PA $6: 1$

Figure 5 shows that after the first cycle the carbon continues to act as a catalyst so that the stabilization of the absorbance value shown in Figure 3 is not a consequence of the saturation of the active sites by the substrate. However, there is a gradual decline in activity. X-ray fluorescence analysis (see Supplementary Material) showed the presence of relatively large concentrations of sulphur on the carbon after the third cycle, so that the decrease in activity could be related to the adsorption of polysulfides on the carbon surface, taking into account that as the length of the polysulphur chain increases so does the adsorption strength on the carbon surface as the polysulfide becomes more hydrophobic. 


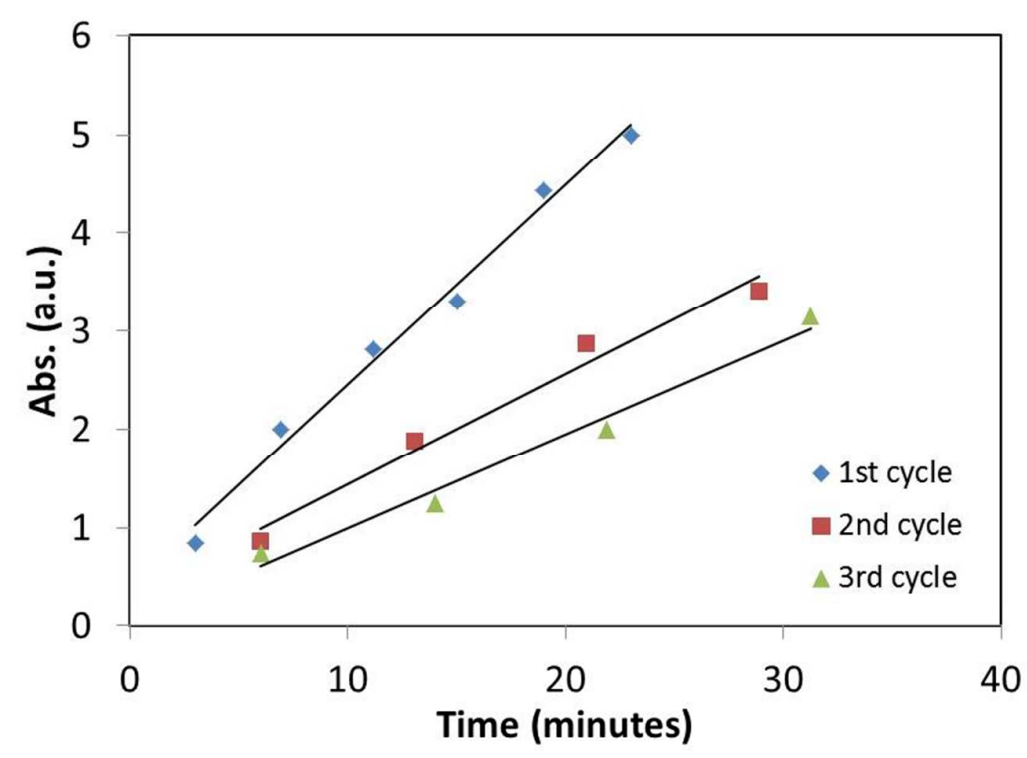

Figure 5. Kinetic data of three consecutive sulfide oxidations

\section{Conclusions}

The activation of mesophase pitch produces nanostructured carbons containing graphitic domains in the structures, with very high surface area and micro and mesopore volumes. These graphitic layers have sufficient concentration of oxygen functionalities active for the oxidation of aqueous sulfide, but when the carbon is essentially microporous the activity is limited by the accessibility of the sulfide to the active sites, unlike in activated carbons with a wider porosity, which exhibited a very high catalytic activity. In fact, the rate constant with the most activated carbon is 100 times larger than that of a commercial activated carbon used as reference.

The conversion capacity from sulfide to disulfide of most of the studied activated carbons reaches the same limit. However, the time required to reach this limit depends mainly on porosity, especially mesoporosity. In the activated carbons with higher mesopore volume the access of sulfide to the pores and the 
exit of the relatively large polysulfides, i.e. $\mathrm{S}_{2}{ }^{2-}-\mathrm{S}_{4}{ }^{2-}$, out of the carbon particle is improved. However, the adsorption of the polysulfides formed during the oxidation results in a decrease of the carbon efficiency with the number of cycles, which can be considered advantageous since it supposes a sulfide removal from the solution when being transferred to the activated carbon as polysulfide.

\section{Acknowledgement}

The authors wish to thank CNPq, CAPES, INCT, PRPq-UFMG and Prometeo II/2014/004 for the financial support

\section{References}

(1) Carrera, L.; Springer, F.; Lipeme-Kouyi, G.; Buffiere, P. A Review of Sulfide Emissions in Sewer Networks: Overall Approach and Systemic Modelling. Water Sci. Technol. 2016, 73 (6), 1231-1242.

(2) Yuan, H.; Zhu, N. Progress in Inhibition Mechanisms and Process Control of Intermediates and by-Products in Sewage Sludge Anaerobic Digestion. Renew. Sustain. Energy Rev. 2016, 58, 429-438.

(3) Burgess, J. E.; Parsons, S. A.; Stuetz, R. M. Developments in Odour Control and Waste Gas Treatment Biotechnology: A Review. Biotechnol. Adv. 2001, 19 (1), 35-63.

(4) Zhao, W.; Zou, Y.; Matsuda, K.; Zou, Z. Characterization of the Effect of Hydrogen Sulfide on the Corrosion of X80 Pipeline Steel in Saline Solution. Corros. Sci. 2016, 102, 455-468. 
(5) Nassar, I. M.; Noor El-Din, M. R.; Morsi, R. E.; El-Azeim, A. A. A.; Hashem, A. I. Eco Friendly Nanocomposite Materials to Scavenge Hazard Gas H2S through Fixed-Bed Reactor in Petroleum Application. Renew. Sustain. Energy Rev. 2016, 65, 101-112.

(6) Dos Santos, J. P. L; de Carvalho Lima Lobato, A. K.; Moraes, C.; de Lima Cunha, A.; da Silva, G. F.; dos Santos, L. C. L. Comparison of Different Processes for Preventing Deposition of Elemental Sulfur in Natural Gas Pipelines: A Review. J. Nat. Gas Sci. Eng. 2016, 32, 364-372.

(7) Sakanishi, K.; Wu, Z.; Matsumura, A.; Saito, I.; Hanaoka, T.; Minowa, T.; Tada, M.; Iwasaki, T. Simultaneous Removal of H2S and COS Using Activated Carbons and Their Supported Catalysts. Catal. Ultra-clean Fuels Prod. Ultra-clean Fuels Prod. 2005, 104 (1), 94-100.

(8) Pfeiffer, J. B. Sulfur Removal and Recovery from Industrial Processes; John B. Pfeiffer, Ed.; AMERICAN CHEMICAL SOCIETY, 1975; Vol. 139.

(9) León, M.; Jiménez-Jiménez, J.; Jiménez-López, A.; Rodríguez-Castellón, E.; Soriano, D.; Nieto, J. M. L. Vanadium Oxide-Porous Phosphate Heterostructure Catalysts for the Selective Oxidation of $\mathrm{H} 2 \mathrm{~S}$ to Sulphur. Solid State Sci. 2010, 12 (6), 996-1001.

(10) Cunha, I. T.; Teixeira, I. F.; Mesquita, J. P.; Ardisson, J. D.; Binatti, I.; Pereira, F. V.; Lago, R. M. Cellulose Nanocrystals Assembled on the Fe3O4 Surface as Precursor to Prepare Interfaced C/Fe3O4 Composites for the Oxidation of Aqueous Sulfde. J. Braz. Chem. Soc. 2016, 27 (2), 363-371. 
(11) Klimmek, O.; Stein, T.; Pisa, R. R.; Simon, J.; Kroger, A.; Kröger, A. The Single Cysteine Residue of the Sud Protein Is Required for Its Function as a Polysulfide-Sulfur Transferase in Wolinella Succinogenes. Eur. J. Biochem. 1999, 263 (1), 79-84.

(12) Du, C.-; Perlinger, J. A.; Kalluri, V. M.; Venkatapathy, R.; Angst, W. Addition of Hydrogen Sulfide to Juglone. Environ. Sci. Technol. 2002, 36 (12), 2663-2669.

(13) Lefers, J. B.; Koetsier, W. T.; Van Swaaij, W. P. M. The Oxidation of Sulphide in Aqueous Solutions. Chem. Eng. J. 1978, 15, 111-120.

(14) Harrison, A. P. The Acidophilic Thiobacilli and Other Acidophilic Bacteria That Share Their Habitat. Annu. Rev. Microbiol. 1984, 38 (1), 265-292.

(15) Friedrich, C. G.; Rother, D.; Bardischewsky, F.; Quentmeier, A.; Fischer, J.; Ouentmeier, A.; Fischer, J. Oxidation of Reduced Inorganic Sulfur Compounds by Bacteria: Emergence of a Common Mechanism? Appl. Environ. Microbiol. 2001, 67 (7), 2873-2882.

(16) De Castro, M. M.; Martinez-Escandell, M.; Molina-Sabio, M.; RodriguezReinoso, F. Hydrogen Adsorption on $\mathrm{KOH}$ Activated Carbons from Mesophase Pitch Containing Si, B, Ti or Fe. Carbon N. Y. 2010, 48 (3), $636-644$.

(17) Rodriguez-Reinoso, F.; Molina-Sabio, M.; Munecas, M. A. Effect of Microporosity and Oxygen Surface Groups of Activated Carbon in the Adsorption of Molecules of Different Polarity. J. Phys. Chem. 1992, 96 (6), 2707-2713. 
(18) Schütz, M.; Klughammer, C.; Griesbeck, C.; Quentmeier, A.; Friedrich, C. G.; Hauska, G.; Schotz, M.; Klughammer, C.; Griesbeck, C.; Quentmeier, A.; et al. Sulfide-Quinone Reductase Activity in Membranes of the Chemotrophic Bacterium Paracoccus Denitrificans GB17. Arch. Microbiol. 1998, 170 (5), 353-360.

(19) Lemos, B. R. S.; Teixeira, I. F.; de Mesquita, J. P. J. P.; Ribeiro, R. R.; Donnici, C. L. C. L.; Lago, R. M. Use of Modified Activated Carbon for the Oxidation of Aqueous Sulfide. Carbon N. Y. 2012, 50 (3), 1386-1393.

(20) Zhang, B.; Song, J.; Yang, G.; Han, B. Large-Scale Production of HighQuality Graphene Using Glucose and Ferric Chloride. Chem. Sci. 2014, 5 (12), 4656-4660.

(21) Tang, J.; Huang, Y.; Gong, Y.; Lyu, H.; Wang, Q.; Ma, J. Preparation of a Novel Graphene oxide/Fe-Mn Composite and Its Application for Aqueous Hg(II) Removal. J. Hazard. Mater. 2016, 316, 151-158.

(22) Włodarczyk D.; Urban, M.; Strankowski, M.. Chemical Modifications of Graphene and Their Influence on Properties of Polyurethane Composites: A Review. Phys. Scr. 2016, 91 (10), 104003.

(23) Lemos, B. R. S.; Teixeira, I. F.; Machado, B. F.; Alves, M. R. A.; de Mesquita, J. P.; Ribeiro, R. R.; Bacsa, R. R.; Serp, P.; Lago, R. M. Oxidized Few Layer Graphene and Graphite as Metal-Free Catalysts for Aqueous Sulfide Oxidation. J. Mater. Chem. A 2013, 1 (33), 9491-9497.

(24) Casco, M. E.; Martinez-Escandell, M.; Silvestre-Albero, J. J.; RodriguezReinoso, F.; Martínez-Escandell, M.; Silvestre-Albero, J. J.; Rodríguez- 
Reinoso, F. Effect of the Porous Structure in Carbon Materials for CO2 Capture at Atmospheric and High-Pressure. Carbon N. Y. 2014, 67, 230235.

(25) Casco, M. E.; Martinez-Escandell, M.; Kaneko, K.; Silvestre-Albero, J.; Rodriguez-Reinoso, F. Very High Methane Uptake on Activated Carbons Prepared from Mesophase Pitch: A Compromise between Microporosity and Bulk Density. Carbon N. Y. 2015, 93, 11-21.

(26) Strelko, J.; Malik, D. J.; Streat, M. Characterisation of the Surface of Oxidised Carbon Adsorbents. Carbon N. Y. 2002, 40 (1), 95-104.

(27) Silverstein, R. M.; Bassler, C. G.; Morril, T. C. Spectrometric Identification of Organic Compounds; John Wiley and Sons Inc.: New York, 1991; Vol. 2.

(28) Jurgis, B.; Maryte, D. Investigation of the Functional Groups on the Surface of Activated Carbons. J. Serbian Chem. Soc. 2004, 69 (5), 363375.

(29) Linkous, C. A.; Huang, C.; Fowler, J. R. UV Photochemical Oxidation of Aqueous Sodium Sulfide to Produce Hydrogen and Sulfur. J. Photochem. Photobiol. A Chem. 2004, 168, 153-160.

(30) Xin, S.; Gu, L.; Zhao, N. H.; Yin, Y. X.; Zhou, L. J.; Guo, Y. G.; Wan, L. J. Smaller Sulfur Molecules Promise Better Lithium-Sulfur Batteries. J. Am. Chem. Soc. 2012, 134 (45), 18510-18513.

(31) Jaroudi, O. El; Picquenard, E.; Demortier, A.; Lelieur, J.-P.; Corset, J. Polysulfide Anions. 1. Structure and Vibrational Spectra of the S 2 2-and 
S 3 2-Anions. Influence of the Cations on Bond Length and Angle. 


\section{Narrow micropores}

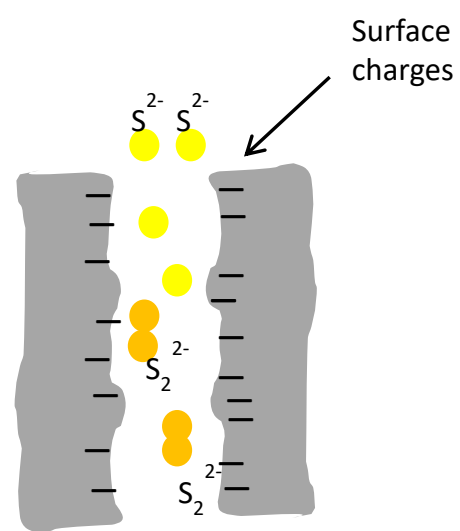

Limited $\mathrm{S}^{2-}$ access to active sites
Mesopores / Micropores

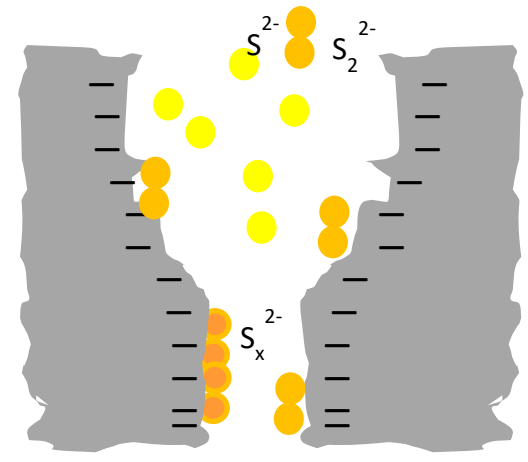

Better access to active sites

GRAPHICAL ABSTRACT 